\title{
INTELLIGENT MONITORING SYSTEM FOR GARBAGE WASTE BINS USING ARDUINO
}

\author{
R.B.Tapase ${ }^{1}$, Ashwini Mohite ${ }^{2}$, Trupti Kadam ${ }^{3}$, Puja Deshmukh ${ }^{4}$ \\ ${ }^{1}$ Assistant Professor, Department of Electronics and Telecommunication Engineering, Annasaheb Dange College of \\ Engineering and Technology Ashta, Maharashtra, India \\ ${ }^{2}$ Student, Department of Electronics and Telecommunication Engineering, Annasaheb Dange College of Engineering \\ and Technology Ashta, Maharashtra, India \\ ${ }^{3}$ Student, Department of Electronics and Telecommunication Engineering, Annasaheb Dange College of Engineering \\ and Technology Ashta, Maharashtra, India \\ ${ }^{4}$ Student, Department of Electronics and Telecommunication Engineering, Annasaheb Dange College of Engineering \\ and Technology Ashta, Maharashtra, India
}

\begin{abstract}
Today we see the garbage waste bins are overflowing and all garbage is split out from dust bins, which results into unhygienic condition, illness and bad smell for all people near that area. Hence, we are designing the system based on arduino for monitoring garbage from particular area to avoid pollution, unhygienic condition, bad smell, etc. The dustbins are interfaced with microcontroller based system having ultrasonic sensor showing the current status of garbage on android device. When garbage reaches the level of sensor, then that indication will be given to the microcontroller unit and microcontroller sends signal to the user through GSM. So continuous monitoring of garbage bins will keep the environment clean.
\end{abstract}

Keywords: Solid Waste, GSM, Ultrasonic Sensor, Arduino.

\section{INTRODUCTION}

A big challenge in the cities is solid waste management. "Swatch Bharat Abhiyan" Prime Minister Mr. Narendra Modi's ambitious project to make India clean country aims to teach citizens to reduce and even to clean their own waste. India generates about 60 million tonnes of crash every year.10 million tonnes garbage is generated in just metropolitan cities like Delhi, Mumbai, Chennai, etc.This project will give us efficient way to keep our environment clean and green.

In present day, many times we see that garbage bins or dustbins placed at public places are overflowing due to increase in solid waste everyday. It creates unhygienic conditions for all people and creates bad smell around the surroundings this leads in spreading some diseases and human illness, to avoid such situation we are designing "Intelligent Monitoring System for Garbage Waste bins". In this proposed system there are multiple dust bins are located throughout the city, this dust bins are provided with low cost embedded devices. Global system for mobile communication is the latest tread used now a days can be used for our project. Sensors are placed above the dust bin. It will detect whether the garbage is at low, middle or highest level.

The main control unit consist of ardunio it will receive the output signal of sensor, process it and according to that it will send the message to office user. Along with detection of depth of garbage simultaneously it will detect presence of flame or smoke. The work consists of an experimental approach towards waste management and finding an alternative to conventional materials in flexible pavements[8].

\section{LITERATURE REVIEW}

[1]. IoT based waste management system for smart cities by Prakash, Prabhu gives idea about implementation of real time waste management system using smart dustbins to check the fill level of smart dustbins whether the dustbins are full or not. In this system information of all smart dustbins can be accessed from anywhere and anytime by the concern person and he/she can take decision accordingly.

[2]. In waste bin monitoring system using integrated technologies by Kanchan Mahajan the sensor is placed in the garbage bin at maximum level, if that level is crossed by garbage in bin, then sensor will sense that and communicate to ARM7 controller through Zig Bee technology.

[3]. City garbage collection indicator using RF(ZigBee) and GSM technology. This paper gave transmission of data to receiver side and also the main channel follow of the project.

[4]. Garbage and street light monitoring system using internet of things by Prof.R.M.Sahu, Akshay Godse, Pramod Shinde, Reshma Shinde includes garbage as well as street light monitoring which avoides accident during night. This paper will help to reduce power consumption and manpower. 
[5]. Raghumani Singh, C. Dey, M. The objective is to determine the characterization of the waste and the current system of management activities. The paper highlights an overview of the current municipal solid waste management(MSWM) system of Thoubal Municipality and it concludes with few suggestions, which may be beneficial to authorities to work towards further improvement of current management systems.

\section{METHODOLOGY}

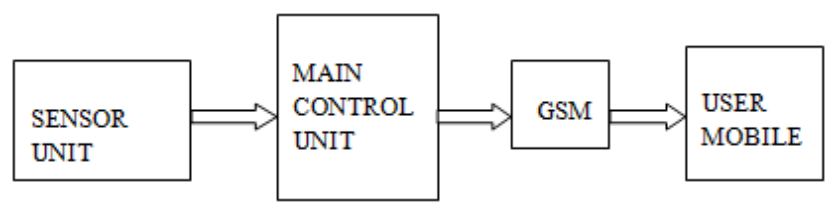

Fig -1: Methodology

Fig. 1 shows how the status of garbage dust bins is received by the user on mobile. Sensor unit consist of IR sensor or ultrasonic sensor or flame detection sensor. The main control unit consist of ardunio, signal passes through ardunio and reaches the user mobile through GSM.

\subsection{Level - 1 Detection of Garbage}

An ultrasonic sensor is used to detect the level of garbage in the dust bin, it will detect whether the garbage is at low, middle or highest level and produce analog signal.

\subsection{Level - 2 Transmission of Signal}

The output signal of sensor is in analog form it is necessary to convert it into digital signal. This signal is given to the main control unit i.e. ardunio. Arduino reads the data from sensor and process it.

\subsection{Level - 3 Receiving of Signal}

The signal transmitted from the control unit is received on the user mobile through GSM.

\section{PROPOSED SYSTEM}

Implementation of this system can be expensive but by considering number of garbage bins required in India this can become a great advantage for country as well as environment.

\subsection{System Architecture}

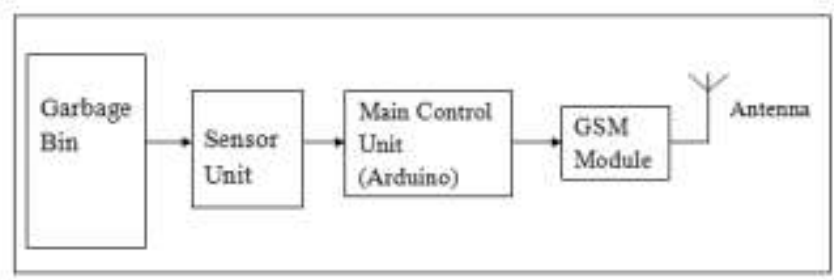

Fig -2: Transmitter

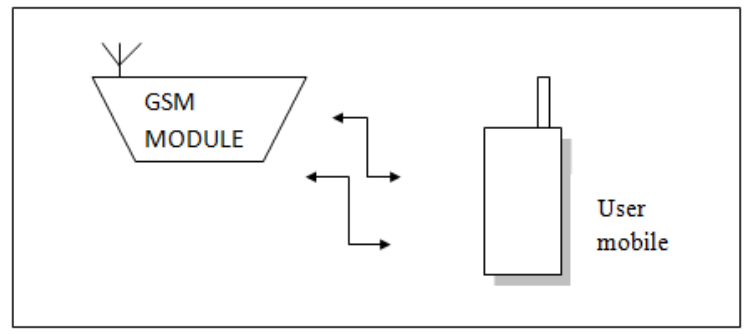

Fig -2: Recevier

\subsection{Sensor Unit}

The sensor unit consist of ultrasonic sensor or IR sensor, flame sensor used to recognize garbage level in the dust bin and to detect presence of flame.

\subsection{Main Control Unit (Arduino)}

The main control unit consist of arduino. The output signal of the sensor is given to the arduino. The program is written on the arduino software, it as an open source software and make easy to code and upload it on board.

\subsection{GSM Module}

Global system for mobile communication (GSM), originally Group Special Mobile commonly known as GSM, is standard set development by the (ETSI) to describe protocols for second generation digital cellular networks used by mobile phones. GSM module has SIM card it sends message to user, when an error introduced. They are used for sending and receiving SMS and MMS alerts. GSM is world's most popular technology, it was develop to solve the fragmentation problems of the first cellular system in Europe[7]

\subsection{Flow Chart}

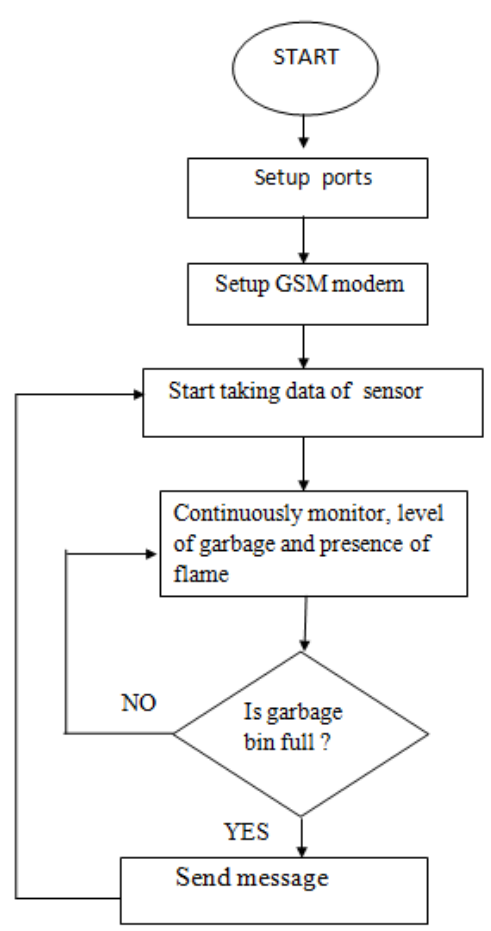

Fig -2: Flow chart 
Fig 4.5 shows the flowchart of garbage monitoring system. Here the sensor is deployed into the dustbin to check the garbage level and presence of flame. All ports and GSM modem is set up at first then output of sensor is continuously monitored. When dust bin is full system starts taking data from sensor and sends message to the user through GSM.

\section{CONCLUSION}

By implementing this project we can able to monitor the level of garbage in the dust bins placed at public places, according to that we can collect garbage of particular which will avoid overflow conditions and helps to reduce pollution as well as different hazards of health. This system will reduce the wastage of fuel by reducing number of trips of garbage collection vehicle. Hence intelligent garbage monitoring system will makes the garbage collection more efficient.

\section{FUTURE ENHANCEMENT}

While dealing with more number of dustbins in city level we can use video processing, which will improve the reliability of circuit. Also we can add GPS modem to this project hence, it will help to track the position of dust bin. We can create new application also for garbage monitoring which will show overview of dustbin.

\section{REFERENCES}

[1] Prakash, Prabhu, "IoT based management system for smart cities", International Journal of Innovative Research in Science, Engineering and Technology, vol 4, Issue 2, February 2016.

[2] Kanchan Mahajan, Prof J. S. Chitode,"Waste Bin Monitoring system Using Integrated Technologies", International Journal of Innovative Research in Science, Engineering and Technolgy(An ISO 3297:2007 Certified Organization) Vol 3, Issue 7, July 2014.

[3] Prof.R.M.Sahu, Akshay Godse, Pramod Shinde, Reshma Shinde," Garbage and Street Light Monitoring System using Internet of Things", International Journal of Innovative Resarch in Electrical, Electronics, Instrumentation and Control Engineering, Vol 4, Issue 4, 4 April 2016.

[4] M. Al-Maaded, N. K. Madi, Ramazan Kahraman, A. Hodizic, N. G. Ozerkar, An overview of Solid Waste Management and Plastic Recyling in Qatar, Springer Journal of polymer and the Environment, March 2012, Volume 20, Issue 1, pp 186-194.

[5] Raghumani Singh, C. Dey, M. Solid Waste Management of Thoubal Municipality, Manipur- a case study Green Technology and Environment Conservation(GTEC 2011), 2011 International Conference Chennai 21-24.

[6] Vikrant Bhor,"Smart Garbage Management System International Journal of Engineering Research \& Technology(IJERT), Vol 4 Issue 03, March201552000.

[7] Ms. S. N. Patil, Ms. S. S. Jagdale, Ms. A. T. Gharall Asst.Prof. R. B. Tapase,'Wireless ECG Monitoring
System", International Researched Journal of Engineering and Technology, Vol 03, Issue 03, March 2016.

[8] Rajashree Tapase, Digvijay Kadam and Anand Tapase," Consumption of Electronics waste in Quality Enhancement of Road", Journal of Environmental Research and Development, Vol 9, issue3,January2015.

\section{BIOGRAPHIES}

[1]. Prof.Ms.R.B.Tapase, Assistant Professor, Department of Electronics and Telecommunication Engineering, Annasaheb Dange College of Engineering and Technology Ashta, Maharashtra, India

[2]. Ms.Ashwini Mohite,Student,Department of Electronics and Telecommunication, Engineering, Annasaheb Dange College of Engineering and Technology Ashta, Maharashtra, India.

[3]. Ms.Trupti Kadam,Student ,Department of Electronics and Telecommunication Engineering, Annasaheb Dange College of Engineering and Technology Ashta, Maharashtra, India.

[4]. Ms. Puja Deshmukh,Student,Department of Electronics and Telecommunication Engineering, Annasaheb Dange College of Engineering and Technology Ashta, Maharashtra, India. 